ROCZNIK ADMINISTRACJI PUBLICZNEJ 2021 (7)

ARTYKUŁY / ARTICLES

Prawo i administracja Unii Europejskiej

Law and Administration of the European Union

\title{
Wykładnia definicji legalnej nieprawidłowości w świetle wyroku Trybunału Sprawiedliwości Unii Europejskiej w sprawie C-406/14 - pytanie prejudycjalne WSA w Warszawie
}

Poszczególne państwa członkowskie UE nie są odpowiedzialne jedynie za dystrybucję środków pochodzących z funduszy unijnych, ale również za weryfikację prawidłowości ich wydatkowania oraz odzyskiwanie nieprawidłowo wydatkowanych środków ${ }^{2}$. W tym ostatnim aspekcie, kluczowe

1 mgr Grzegorz Karwatowicz, GWW Grynhoff i Partnerzy Radcowie Prawni i Doradcy Podatkowi Sp. P., https://orcid.org/0000-0002-5028-203X.

2 Jak expressis verbis wynika $\mathrm{z}$ przepisów prawa UE, za weryfikację prawidłowości wydatkowania środków z funduszy UE oraz odzyskiwanie środków nieprawidłowo wydatkowanych, odpowiadają w pierwszej kolejności państwa członkowskie. Jeżeli jednak państwa członkowskie nie wywiązują się w sposób należyty z przedmiotowych zadań, wówczas Komisja uprawniona jest samodzielnie dokonać niezbędnych korekt finansowych. Taki stan prawa obowiązuje nie tylko na gruncie rozporządzenia Rady nr 1083/2006 z dnia 11 lipca 2006 r. ustanawiającego przepisy ogólne dotyczące Europejskiego Funduszu Rozwoju Regionalnego, Europejskiego Funduszu Społecznego oraz Funduszu Spójności i uchylające rozporządzenie nr 1260/1999 (Dz. U. UE z dn. 31.7.2006 r., L 210m s. 25 i n. ze zm., dalej: „rozporządzenie 1083/2006”) właściwego dla perspektywy finansowej 2007-2013, którego wykładni dotyczyło pytanie prejudycjalne Wojewódzkiego Sądu Administracyjnego w Warszawie (dalej: „WSA w Warszawie") i wyrok Trybunału Sprawiedliwości Unii Europejskiej, ale również właściwego dla perspektywy finansowej 2014-2020 rozporządzenia Parlamentu Europejskiego i Rady nr 1303/2013 z dnia 17 grudnia 2013 r. ustanawiającego wspólne przepisy dotyczące Europejskiego Funduszu Rozwoju Regionalnego, Europejskiego Funduszu Społecznego, Funduszu Spójności, Europejskiego Funduszu Rolnego na rzecz Rozwoju Obszarów Wiejskich oraz Europejskiego Funduszu Morskiego i Rybackiego oraz ustanawiające przepisy ogólne dotyczące Europejskiego Funduszu Rozwoju Regionalnego, Europejskiego Funduszu Społecznego, Funduszu Spójności i Europejskiego Funduszu Morskiego i Rybackiego oraz uchylające rozporządzenie Rady (WE) nr 1083/2006 (Dz. U. UE z dn. 20.12.2013 r., L 347, s. 320 i n., dalej: „rozporządzenie 1303/2013”). W obu wyżej wskazanych rozporządzeniach przepisy statuujące pojęcie nieprawidłowości, podstawę do dokonywania korekt finansowych przez państwa członkowskie, jak i dokonywania korekt finansowych przez Komisję są, co do istoty regulacji tożsame. 
znaczenie posiada definicja legalna ${ }^{3}$ nieprawidłowości ${ }^{4}$. To bowiem wystąpienie nieprawidłowości stanowi usprawiedliwioną podstawę dokonania korekty finansowej, która polega na całkowitym lub częściowym ${ }^{5}$ anulowaniu wsparcia $z$ funduszy UE do realizowanego przez beneficjenta przedsięwzięcia (projektu) ${ }^{6}$.

Określone wątpliwości, co do wykładni definicji legalnej nieprawidłowości posiadał WSA w Warszawie, który w postanowieniu z dnia 3 czerwca

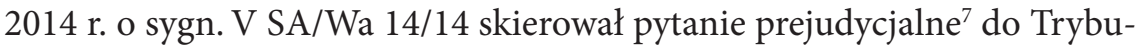

$3 \mathrm{Na}$ temat definicji legalnych zob. P. Saługa, Sposoby wyodrębniania definicji legalnych, „Państwo i Prawo” 2008, nr 5, s. 76 i n., A. Jopek-Bosiacka, Teoretycznoprawne i logiczne uwarunkowania przekładu prawnego, Warszawa 2019, s. 75 i n.

4 Statuujący definicję legalną nieprawidłowości art. 2 pkt 7 rozporządzenia 1083/2006 stanowi: „nieprawidłowośc”: jakiekolwiek naruszenie przepisu prawa wspólnotowego wynikające $z$ działania lub zaniechania podmiotu gospodarczego, które powoduje lub mogłoby spowodować szkodę $w$ budżecie ogólnym Unii Europejskiej $w$ drodze finansowania nieuzasadnionego wydatku $z$ budżetu ogólnego. Na temat definicji legalnej nieprawidłowości zob. G. Karwatowicz, A. Zawiślańska, Korekty finansowe za naruszenie prawa zamówień publicznych w projektach unijnych, Wrocław, 2013, s. 46 i n., J. Łacny, Ochrona interesów finansowych Unii Europejskiej w dziedzinie polityki spójności, Warszawa 2010, s. 138 i n., M. Sochańska, M. Stepaniuk, Korekty finansowe w procesie udzielania zamówień publicznych. Kontrola postępowań współfinansowanych ze środków unijnych, Warszawa 2019, s. 4 i n.

5 W zależności od wagi i charakteru stwierdzonej nieprawidłowości oraz strat, jakie stwierdzona nieprawidłowość wyrządziła budżetowi UE. Dokonana korekta finansowa powinna być bowiem proporcjonalna. Powyższe nie tylko wynika expressis verbis z przepisów prawa UE, ale również zostało potwierdzone w orzecznictwie TSUE. Zob. wyroki w sprawach: C-101/07 P i C-110/07 P, Coop de France betail et viande i inni przeciwko Komisji, EU:C:2008:741, pkt 130; C-93/17, Komisja przeciwko Grecji, EU:C:2018:903, pkt 154; C-196/13 Komisja przeciwko Włochom, EU:C:2014:2407, pkt 117 i 118. Zob. również: J. Maliszewska-Nienartowicz, Rozwój zasady proporcjonalności w europejskim prawie wspólnotowym, „Studia Europejskie” 2006, s. 60 oraz J. Łacny, Korekty finansowe nakładane przez Komisję Europejska na państwa członkowskie za niezgodnie z prawem wydatkowanie funduszy Unii Europejskiej, Warszawa 2017, s. 50 i n.

6 Zob. J. Łacny, Korekty finansowe nakładane za niezgodne z prawem wydatkowanie funduszy unii europejskiej - wyrok Trybunału Sprawiedliwości z 14.07.2016 r., C-406/14, Wrocław - miasto na prawach powiatu przeciwko ministrowi infrastruktury i rozwoju [w:] S. Biernat, Kamienie milowe orzecznictwa Trybunału Sprawiedliwości Unii Europejskiej, SIP Lex.

$7 \mathrm{Na}$ uwagę zasługuje fakt, iż WSA w Warszawie, w postanowieniu z dnia 3 czerwca 2014 r. o sygn. akt V SA/Wa 14/14 skierował dwa pytania prejudycjalne do Trybunału. Przy czym od razu należy dodać, iż jedno z nich jakkolwiek nie dotyczyło definicji legalnej nieprawidłowości. Odnosiło się ono do stosowania art. 25 dyrektywy 2004/18/ WE Parlamentu Europejskiego i Rady z dnia 31 marca 2004 r. w sprawie koordynacji procedur udzielania zamówień publicznych na roboty budowlane, dostawy i usługi (Dz. Urz. UE z 2004 r., L 134, s. 114, dalej: „dyrektywa klasyczna”), a ściślej do kwestii dopuszczalności ograniczenia przez zamawiającego, w treści specyfikacji istotnych warunków zamówienia w postępowaniu o udzielenie zamówienia publicznego, możliwości angażowania podwykonawców przez generalnego wykonawcę robót budowlanych będących przedmiotem zamówienia publicznego. 
nału Sprawiedliwości Unii Europejskiej (dalej jako: „Trybunał”) odnoszące się w swoim przedmiocie do definicji legalnej nieprawidłowości. Artykuł stanowi analizę sprawy i wyroku Trybunału z dnia 14 lipca 2016 r. w sprawie C-406/14 Wrocław - Miasto na prawach powiatu przeciwko Ministrowi Infrastruktury i Rozwoju.

Przyjętą przez autora metodą badawczą jest metoda prawno-dogmatyczna. Jest ona właściwą metodą dla analizy przepisów prawa oraz orzeczeń sądów.

\section{Pytanie prejudycjalne w zakresie definicji legalnej nieprawidłowości i sposób jego sformułowania}

WSA w Warszawie zadał Trybunałowi dwa pytania prejudycjalne. Pierwsze z pytań prejudycjalnych dotyczyło zgodności postępowania beneficjenta środków unijnych $\mathrm{z}$ art. 25 dyrektywy klasycznej ${ }^{8}$. Beneficjent środków unijnych zobowiązany był do stosowania przepisów o zamówieniach publicznych, a ich naruszenie mogło posiadać konsekwencje związane z utratą dofinansowania z funduszu UE. Do definicji legalnej nieprawidłowości odnosiło się drugie pytanie prejudycjalne, które brzmiało w sposób następujący: W razie odpowiedzi negatywnej na pytanie pierwsze, czy skutkiem zastosowania wymogu opisanego $w$ pytaniu pierwszym $w$ postępowaniu o udzielenie zamówienia publicznego, jest takie naruszenie przepisów prawa Unii Europejskiej, które uzasadnia konieczność dokonania korekty finansowej $w$ trybie art. 98 rozporzadzenia Rady (WE) z dnia 11 lipca 2006 r., nr 1083/2006/WE, ustanawiajace przepisy ogólne dotyczace Europejskiego Funduszu Rozwoju Regionalnego, Europejskiego Funduszu Społecznego oraz Funduszu Spójności i uchylające rozporządzenie (WE) nr 1260/1999 (Dz. Urz. UE z 2006 r., L 210, s. 25).

Sam sposób sformułowania drugiego z pytań prejudycjalnych przez sąd odsyłający budzi określone wątpliwości. Otóż art. 267 lit. b) Traktatu o funkcjonowaniu Unii Europejskiej (Dz. U. UE z dn. 26.10.2012 r., C 326, s. 1 i n., dalej: „TFUE”) stanowi, że Trybunał jest właściwy do orzekania

8 Przepis art. 25 ówcześnie obowiązującej dyrektywy z dnia 31 marca 2004 r. w sprawie koordynacji procedur udzielania zamówień publicznych na roboty budowlane, dostawy i usługi (Dz. U. UE z dn. 30.04 .2004 r., L 134, s. 114 i n., dalej: „dyrektywa klasyczna”) został implementowany do art. 36 ust. 5 ówcześnie obowiązującej ustawy z dnia 29 stycznia 2004 r. Prawo zamówień publicznych (Dz. U. z 2004 r. Nr 19 po 117, ze zm., dalej: „Pzp”). Art. 36 ust. 5 Pzp stanowił, iż: Zamawiający może określić w specyfikacji istotnych warunków zamówienia, która część zamówienia nie może być powierzona podwykonawcom. Zamawiający (beneficjent) w treści dokumentacji przetargowej ograniczył udział podwykonawców w realizacji przedmiotu zamówienia, a zdaniem instytucji kontrolującej wydatkowanie środków unijnych dokonał tego w sposób nadmierny, a zatem nieuprawniony. 
w trybie prejudycjalnym o wykładni ${ }^{9}$ aktów przyjętych przez instytucje, organy lub jednostki organizacyjne UE. Jak słusznie stwierdził B. Gruszczyński - wykładnia to rozumienie treści przepisu ${ }^{10}$. Tymczasem drugie z pytań prejudycjalnych (to dotyczące definicji legalnej nieprawidłowości) sformułowane zostało, w zasadzie, w sposób właściwy dla pytania o subsumcję (zastosowanie przepisu) ${ }^{11}$. WSA w Warszawie, jako sąd odsyłający, zadał pytanie TSUE, czy w sytuacji, w której ten uznałby, że działanie beneficjenta (zamawiającego) nie znajduje usprawiedliwionych podstaw na gruncie art. 25 dyrektywy klasycznej, to czy takie naruszenie stanowi podstawę do dokonania korekty finansowej, ergo stanowi nieprawidłowość, bowiem to jej wystąpienie warunkuje dokonanie korekty finansowej. Pytanie nie odnosi się do wątpliwości w zakresie rozumienia przepisu, a oceny prawnej naruszenia przepisów o zamówieniach publicznych. $\mathrm{Z}$ pola widzenia nie może umknąć przy tym fakt, iż celem instytucji pytania prejudycjalnego jest zapewnienie jednolitej wykładni prawa $\mathrm{UE}^{12}$, nie zaś udzielenie przez Trybunał wsparcia krajowemu sądowi odsyłającemu poprzez rozstrzygnięcie zagadnienia wstępnego wymagającego stosowania prawa UE.

9 Również o ich ważności. Zob. J. Michalska, Pytania prejudycjalne sądów do TS UE [w:] Zasada pierwszeństwa prawa Unii Europejskiej w praktyce działania organów władzy publicznej RP, M. Jabłoński, S. Jarosz-Żukowska (red.), Wrocław 2015, s. 251 i n.

10 Zob. B. Gruszczyński [w:] B. Dauter, B. Gruszczyński, A. Kabat, M. Niezgódka-Medek Prawo o postępowaniu przed sądami administracyjnymi, Komentarz, Zakamycze 2006, s. 378. Tak również NSA w wyroku z dnia 20 lipca 2011 r. o sygn. akt III FSK $335 / 10$.

11 Na co zwrócono uwagę w doktrynie prawniczej art. 267 TFUE nie wyposaża TS $w$ kompetencje do stosowania prawa, czyli do subsumcji ustalonego przez sąd krajowy stanu faktycznego pod norme prawa unijnego. Tak: J. Skrzydło, Granice kompetencji Trybunału Sprawiedliwości do wydawania orzeczeń prejudycjalnych, „Europejski Przegląd Sądowy" 2017, nr 12, s. 4. Takie stanowisko znajduje swoje potwierdzenie w orzecznictwie Trybunału na co zresztą zwraca uwagę J. Skrzydło w wyżej przytoczonym artykule. Zob. wyroki w sprawach: C-320/88 Staatssecretaris van Financien przeciwko Shipping and Forwarding Enterprise Safe BV, EU:C:1990:61.7 oraz C-222/78, ICAP przeciwko Walter Beventi, EU:C:1979:90.W przedmiocie właściwości TSUE zob. również: A. Sikora, Praktyka Trybunału Sprawiedliwości w postępowaniach na podstawie art. 267 TFUE $w$ świetle orzecznictwa i ostatniej reformy procedury, „Europejski Przegląd Sądowy” 2014 , nr 11, s. 35 i n.

12 Zob. Wprowadzenie do Zaleceń Trybunału dla sądów krajowych dotyczących składania wniosków o wydanie orzeczenia w trybie prejudycjalnym (2018/C 257/01). Przy tym istotną przeszkodą do osiągnięcia jednolitej wykładni prawa UE jest okoliczność, iż „wielojęzyczne” prawo UE w pierwszej kolejności stosowane jest przez organy i sądy krajowe. Zob. T. Grzybowski, B. Dauter (red.), Pytanie prejudycjalne sądu administracyjnego do Trybunału Sprawiedliwości, SIP Lex oraz A. Kalisz, Reguly interpretacyjne stosowane przez ETS, „Europejski Przegląd Sądowy” 2007, nr 2, s. 13. Na marginesie, innym z celów wprowadzenia instytucji pytania prejudycjalnego jest niedopuszczenie do sytuacji, w której w poszczególnych państwach członkowskich rozwinie i utrwali się orzecznictwo niezgodne z prawem UE. Zob. M. Taborowski, Polskie sądy zobowiązane do zwrócenia się z pytaniem prejudycjalnym do ETS w świetle wyroku Lyckeskog, „Europejski Przegląd Sądowy” 2008, nr 8, s. 15. 
Niezależnie od sposobu sformułowania przez WSA w Warszawie drugiego z pytań prejudycjalnych, należy wskazać, iż wątpliwości sądu odsyłającego w zakresie wykładni definicji legalnej nieprawidłowości, z powodzeniem wywieść można $\mathrm{z}$ treści uzasadnienia postanowienia $\mathrm{z}$ dnia 3 czerwca 2014 r. o sygn. akt V SA/Wa 14/14, w tym w szczególności z pkt $20^{13}$. Stanowi on: Ze względu na to, że pojęcie "nieprawidłowości” oznacza jakiekolwiek naruszenie przepisu prawa UE, powodujące rzeczywista lub potencjalna szkodę w budżecie Unii, należy postawić pytanie, czy w zakresie tego pojęcia będa mieścić się wszystkie, czy tylko niektóre uchybienia zasadom udzielania zamówień publicznych. WSA w Warszawie, jako sąd odsyłający, ma zatem wątpliwość w zakresie wykładni definicji legalnej nieprawidłowości w zakresie, w jakim definicja ta odnosi się do szkody potencjalnej w budżecie UE. To dlatego WSA w Warszawie pyta o to, czy wszystkie, czy tylko niektóre naruszenia (uchybienia) zasadom udzielania zamówień publicznych stanowią nieprawidłowość.

Art. 2 pkt 7 rozporządzenia 1083/2006 statuujący definicję legalną nieprawidłowości, w kontekście nieprawidłowości opartej na szkodzie potencjalnej, istotnie można interpretować w sposób dwojaki. Po pierwsze: $w$ ten sposób, że już sam fakt naruszenia przepisów o zamówieniach publicznych niesie za sobą ryzyko uszczerbku finansowego w budżecie UE, a więc stanowi szkodę potencjalną, której właściwa instytucja stwierdzająca nieprawidłowość i dokonująca korekty finansowej nie musi dodatkowo uprawdopodobnić ${ }^{14}$. W takim przypadku, nawiązując do pkt 20 postanowienia WSA w Warszawie z dnia 3 czerwca 2014 r. o sygn. akt V SA/Wa 14/14, $\mathrm{w}$ zakresie pojęcia nieprawidłowości mieściłyby się wszystkie naruszenia przepisów o zamówieniach publicznych. Po drugie: $w$ ten sposób, że sam fakt naruszenia przepisów o zamówieniach publicznych nie jest wystarczający do stwierdzenia nieprawidłowości, a o tym, czy określone naruszenie przepisów o zamówieniach publicznych będzie stanowiło nieprawidłowość opartą na szkodzie potencjalnej w budżecie UE przesądzi fakt jej należytego uprawdopodobnienia - wykazania, że naruszenie nie posiada jedynie formalnego charakteru, a istotnie niesie za sobą ryzyko uszczerbku finansowego w budżecie UE. W takim przypadku, nawiązując do pkt 20 postanowienia WSA w Warszawie z dnia 3 czerwca 2014 r. o sygn. akt V SA/

13 Nie sposób przy tym nie odnieść się do pkt 18 Zaleceń Trybunału dla sądów krajowych dotyczących składania wniosków o wydanie orzeczenia w trybie prejudycjalnym (2018/C 257/01), który stanowi, że pytanie prejudycjalne powinno być sformułowane w sposób zrozumiały sam w sobie, w tym w sposób niewymagający odwoływania się do uzasadnienia wniosku.

$14 \mathrm{Na}$ marginesie należy zauważyć, że w przypadku szkody potencjalnej, a zatem ryzyka faktycznej (rzeczywistej) szkody w budżecie UE, można mówić wyłącznie o jej uprawdopodobnieniu. Szkody opartej na ryzyku nie da się przecież udowodnić. Tak: słusznie NSA w wyroku z dnia 15 września 2015 r. o sygn. akt II GSK 2370/14: „Ta ostatnia okoliczność, czyli wystąpienie potencjalnej szkody siłą rzeczy nie może być „udowodniona”. 
Wa 14/14, w zakresie pojęcia nieprawidłowości nie mieściłyby się wszystkie naruszenia przepisów o zamówieniach publicznych ${ }^{15}$.

Wątpliwości związane ze sposobem sformułowania drugiego z pytań prejudycjalnych nie doprowadziły do stwierdzenia jego niedopuszczalności i odmowy wydania orzeczenia przez Trybunał. W opinii autora powodem takiego stanu rzeczy może być okoliczność, iż Trybunał przyjmuje szerokie rozumienie pojęcia „wykładnia”, a nadto nie stanowi naruszenia właściwości krajowego sądu odsyłającego do ustalenia ram postępowania prejudycjalnego stosunkowo elastyczna interpretacja pytań prejudycjalnych ${ }^{16}$.

\section{Opinia rzecznik generalnej}

Nawiązując, w pierwszej kolejności, do kwestii właściwego sposobu rozumienia drugiego z pytań prejudycjalnych zadanych przez krajowy sąd odsyłający należy zauważyć, że rzecznik generalna E. Sharpston, w opinii przedstawionej w dniu 17 listopada 2015 r., wskazała, że „trudność wiąże się $\mathrm{z}$ warunkiem trzecim" ${ }^{17}$, a zatem sposobem wykładni pojęcia szkody w budżecie UE. Jednocześnie rzecznik generalna wskazała, że „dwa pierwsze warunki” (stan, w którym zamawiający, będący beneficjentem środków UE, dopuścił się naruszenia przepisów prawa oraz stan, w którym stwierdzone naruszenie wynikało $\mathrm{z}$ działania lub zaniechania beneficjenta) bezsprzecznie wystąpiły ${ }^{18}$.

Rzecznik generalna stwierdziła, iż z pewnością pomocne dla ustalenia właściwej wykładni pojęcia nieprawidłowości w rozumieniu art. 2 pkt 7 rozporządzenia 1083/2006 jest to, w jaki sposób interpretowane jest pojęcie nieprawidłowości z rozporządzenia 2988/95 vide art. 1 ust. 2 - drugie z rozporządzeń wprowadza jednolite zasady kontroli, środki administracyjne i kary za działania, które godzą lub mogą godzić w interes finansowy $\mathrm{UE}^{19}$. Za słuszne przy tym uznać należy powołanie się przez rzecznik generalną na wyrok Trybunału w sprawie C-465/10 Chambre de commerce

15 W zakresie definicji legalnej nieprawidłowości zob. J. Odachowski, Pojęcie nieprawidłowości wykorzystania przyznanych środków w prawie UE [w:] W. Miemiec, Europejskie bezzwrotne źródła finansowania polityki regionalnej w Polsce, Wrocław 2012, s. 221 i n.; G. Karwatowicz, J. Odachowski, Nieprawidłowości w zamówieniach publicznych skutkujace nałożeniem korekt finansowych, „Finanse Komunalne” 2009, nr 7-8, s. 88 i n.

16 Zob. A. Wróbel, Pytania prawne sądów państw członkowskich do Trybunału Sprawiedliwości Unii Europejskiej [w:] Stosowanie prawa Unii Europejskiej przez sądy, A. Wróbel (red.), Warszawa 2010, s. 575 i n. - podane za T. Grzybowski, B. Dauter (red.), Pytanie prejudycjalne sq̨du administracyjnego do Trybunału Sprawiedliwości, SIP Lex.

17 ECLI:EU:C:2015:761, pkt 48.

18 ECLI:EU:C:2015:761, pkt 47.

19 ECLI:EU:C:2015:761, pkt 52. 
et d'industrie de l'Indre ${ }^{20}$, w którym Trybunał dokonał wykładni przepisów rozporządzenia 2988/95, a dodatkowo orzekał w sprawie, w której doszło do naruszenia przepisów o zamówieniach publicznych.

$\mathrm{Na}$ fakt ten, rzecznik generalna zwróciła uwagę w dalszej części opinii - w wyroku w sprawie C-465/10 Chambre de commerce et d'industrie de l'Indre Trybunał rozstrzygnął, iż nawet te nieprawidłowości, które nie wywołują konkretnych skutków finansowych, mogą niekorzystnie wpłynąć na interes finansowy $U^{21}$. Okoliczność ta, $w$ treści opinii rzecznik generalnej, została uznana za przedmiotowo istotną $\mathrm{w}$ wykładni definicji legalnej nieprawidłowości $z$ art. 2 pkt 7 rozporządzenia 1083/2006 $6^{22}$ i przesądzającą o tym, że Miasto Wrocław, naruszając przepisy o zamówieniach publicznych, dopuściło się nieprawidłowości, która stanowi uzasadnioną przesłankę dokonania korekty finansowej na podstawie art. 98 ust. 2 rozporządzenia $1083 / 2006^{23}$. Dodatkowo rzecznik generalna przedstawiła dwa dalsze argumenty na rzecz przyjętego stanowiska. Po pierwsze: dofinansowanie projektu unijnego, który nie jest we wszystkich aspektach poprawny, w świetle prawa UE prowadzi do dokonania nieuzasadnionego wydatku. Po wtóre: zastosowanie w przypadku jak wyżej korekty finansowej jest spójne z art. 2 ust. 1 rozporządzenia 2988/95 - ten stanowi, że przyjęte środki administracyjne powinny być $\mathrm{m}$.in. odstraszające ${ }^{24}$.

$\mathrm{W}$ opinii rzecznik generalnej, zdaniem autora, brak jest podniesienia kwestii najistotniejszej z perspektywy wykładni pojęcia nieprawidłowości opartej na tzw. szkodzie potencjalnej (ryzyku faktycznego uszczerbku finansowanego) w budżecie UE. Chodzi tutaj o stanowisko, czy zdaniem rzecznik generalnej już sam fakt naruszenia przepisów o zamówieniach powoduje wystąpienie szkody potencjalnej, czy też o wystąpieniu szkody potencjalnej obok faktu naruszenia przepisów o zamówieniach publicznych decydują okoliczności zaszłe w sprawie, które pozwalają uznać, że naruszenie to niesie za sobą ryzyko szkody w budżecie UE. Rzecznik generalna jednoznacznie stwierdziła, że w jej opinii Miasto Wrocław dopuściło się nieprawidłowości w rozumieniu art. 2 pkt 7 rozporządzenia 1083/2006 i występuje w związku z tym podstawa do dokonania korekty finansowej vide art. 98 ust. 2 rozporządzenia 1083/2006. Przy tym brak odniesienia się do wskazanej przez autora wątpliwości nie pozwala dokonać jednoznacznej

20 ECLI:EU:C:2011:867. TSUE podobnie orzekł w wyroku w sprawie C-408/16 Compania Naţională de Administrare a Infrastructurii Rutiere SA v Ministerul Fondurilor Europene - Direcția Generală Managementul Fondurilor Externe, ECLI:EU:C:2017:940, pkt 60.

21 ECLI:EU:C:2011:867, pkt 47. Rzecznik generalna wyrażając to stanowisko przytoczyła fragment wcześniejszego wyroku Trybunału w sprawie C-199/03 Irlandia przeciwko Komisji, Zb. Orz. s. I-8027, pkt 31.

22 ECLI:EU:C:2015:761, pkt 54.

23 ECLI:EU:C:2015:761, pkt 56.

24 ECLI:EU:C:2015:761, pkt 55. 
wykładni przepisu art. 2 pkt 7 rozporządzenia 1083/2006 w świetle stanowiska rzecznik generalnej. $Z$ treści opinii nie sposób bowiem wywieść, czy zdaniem rzecznik generalnej dochodzi do takich naruszeń przepisów prawa (w realiach sprawy: przepisy o zamówieniach publicznych), które stanowią tzw. formalne naruszenia przepisów prawa - naruszenia, które nie posiadają jakiegokolwiek, niekorzystnego, skutku finansowego dla budżetu UE, w tym również na zasadach ryzyka (tzw. szkoda potencjalna).

Jednocześnie rzecznik generalna szeroko odniosła się do kwestii obliczenia wysokości korekty finansowej, mimo że sąd odsyłający nie zwrócił się do Trybunału o dostarczenie wytycznych w tym zakresie ${ }^{25}$. Na marginesie, stanowisko rzecznik generalnej w zakresie obliczenia wysokości korekty finansowej jest co do zasady trafne. Wysokość korekty finansowej powinna być proporcjonalna (odpowiadać wadze i charakterowi stwierdzonej nieprawidłowości), w tym, w pierwszej kolejności powinna odzwierciedlać straty finansowe poniesione przez $\mathrm{UE}^{26}$. Ustalenie wysokości korekty za pomocą przyjętych stawek ryczałtowych jest tymczasem dozwolone wyłącznie wówczas, gdy w zaszłym w sprawie stanie faktycznym nie zachodzi możliwość „dokonania precyzyjnej oceny strat” poniesionych przez budżet UE. Zgodzić się przy tym należy z rzecznik generalną, że niekiedy precyzyjna ocena strat jest „trudna, a wręcz niemożliwa”27.

\section{Wyrok Trybunału}

Także i Trybunał, tożsamo jak rzecznik generalna, zinterpretował drugie pytanie prejudycjalne sądu odsyłającego jako dotyczące $\mathrm{w}$ istocie sposobu wykładni pojęcia szkody w budżecie UE. Przesądza o tym pkt 42 wyroku z dnia 14 lipca 2016 r., w treści którego Trybunał stwierdził, iż wątpliwości sądu odsyłającego budzi „ostatnia część” definicji legalnej nieprawidłowości w rozumieniu art. 2 pkt 7 rozporządzenia 1083/2006 ${ }^{28}$.

25 Rzecznik generalna stwierdziła, że Chociaż sąd odsyłający nie zwraca się wyraźnie o dostarczenie wytycznych co do sposobu, w jaki należy obliczać wysokość majacych zastosowanie korekt finansowych, jest to kwestia, która wymaga omówienia, ECLI:EU:C:2015:761, pkt 59.

26 ECLI:EU:C:2015:761, pkt 60. W przypadku tego stanowiska, rzecznik generalna powołała się na opinię rzecznika generalnego N. Jääskinena w sprawie C-417/12 P Dania przeciwko Komisji, EU:C:2014:286, pkt 76. Zob. również wyroki w sprawach 15/83 Denkavit Nederland, EU:C:1984:183, pkt 25 oraz T-260/94 Air Inter przeciwko Komisji, EU:T:997:89, pkt 144.

27 ECLI:EU:C:2015:761, pkt 61. Stanowisko to rzecznik generalna oparła na wcześniejszych wyrokach w sprawach: C-346/00 Zjednoczone Królestwo Wielkiej Brytanii i Irlandii Północnej przeciwko Komisji, EU:C:2003:474, pkt 53; C-417/12 P Królestwo Danii przeciwko Komisji, EU:C:2014:2288, pkt 105 oraz C-418/06 Królestwo Belgii przeciwko Komisji, EU:C:2008:247, pkt 136.

28 ECLI:EU:C:2016:562, pkt 42. 
Trybunał, w pierwszej kolejności, zgodził się z rzecznik generalną, iż istotnie UE zmierza do finansowania takich działań, które realizowane są w („całkowitej”) zgodności z prawem unijnym. Trybunał zwrócił przy tym uwagę na istotny niuans, który umknął uwadze rzecznik generalnej E. Sharpston. Chodzi tutaj o okoliczność, iż z definicji legalnej nieprawidłowości z art. 2 pkt 7 rozporządzenia 1083/2006 wynika, że naruszenie przepisów prawa (tutaj: przepisów o zamówieniach publicznych) stanowi nieprawidłowość jedynie wtedy, gdy powoduje ono lub mogłoby spowodować szkodę w budżecie ogólnym Unii...29.

Powyższe jakkolwiek nie podważa zasadności powołania się przez rzecznik generalną na wyrok Trybunału zapadły w sprawie C-465/10 Chambre de commerce et d'industrie de l'Indre ${ }^{30}$. Jednocześnie rzecznik generalna nie do końca prawidłowo zinterpretowała wnioski płynące z tego wyroku. Zawarte w nim stanowisko Trybunału, iż dla stwierdzenia nieprawidłowości nie jest wymagane udowodnienie wystąpienia konkretnych skutków finansowych ${ }^{31}$, nie powinno być interpretowane w ten sposób, że w zasadzie każde naruszenie prowadzi do wystąpienia nieprawidłowości, a wyłącznie w ten sposób, że do stwierdzenia nieprawidłowości, rzeczywisty negatywny wpływ na budżet UE nie jest bezwzględnie wymagany - występują bowiem takie naruszenia przepisów prawa, którym nie sposób przypisać rzeczywistego, negatywnego, wpływu na budżet UE, niemniej wobec których da się wpływ ten uprawdopodobnić (na zasadach ryzyka).

Co przy tym kluczowe - w wyroku w sprawie C 406/14 Wrocław - Miasto na prawach powiatu przeciwko Ministrowi Infrastruktury i Rozwoju, Trybunał odniósł się do kwestii okoliczności, w których naruszenie przepisów prawa (tutaj: przepisów o zamówieniach publicznych) można uznać jako prowadzące do ryzyka wystąpienia szkody w budżecie UE (tzw. szkoda potencjalna). Innymi słowy Trybunał wskazał kwalifikator, który pozwala odróżnić od siebie takie naruszenie przepisów prawa, które co prawda nie niesie za sobą wystąpienia faktycznego (rzeczywistego) uszczerbku finansowego w budżecie UE, niemniej stanowi nieprawidłowość w rozumieniu art. 2 pkt 7 rozporządzenia 1083/2006 opartą na ryzyku wystąpienia takiego uszczerbku (tzw. szkodzie potencjalnej), od takiego naruszenia, które posiada wyłącznie formalny charakter - naruszenie nawet potencjalnie (na zasadach ryzyka) nie zagraża budżetowi UE.

Zdaniem Trybunału, naruszenie przepisów prawa o zamówieniach publicznych stanowić będzie nieprawidłowość „o ile nie można wykluczyć”, że uchybienie to miało lub mogłoby mieć wpływ na budżet $\mathrm{UE}^{32}$. A contrario jeżeli okoliczności mające miejsce w sprawie pozwalają wykluczyć wpływ

29 ECLI:EU:C:2016:562, pkt 44.

30 ECLI:EU:C:2011:867.

31 ECLI:EU:C:2011:867, pkt 47.

32 ECLI:EU:C:2016:562, pkt 45. 
na budżet UE (w tym choćby na zasadach ryzyka), to wówczas naruszenie to posiada wyłącznie formalny charakter i nie stanowi nieprawidłowości w rozumieniu art. 2 pkt 7 rozporządzenia 1083/2006. W takiej zaś sytuacji brak jest podstaw do dokonania korekty finansowej na podstawie art. 98 ust. 2 rozporządzenia 1083/2006.

Należy przy tym zwrócić uwagę na sposób, w jaki Trybunał odpowiedział na drugie z pytań prejudycjalnych sądu odsyłającego. Trybunał udzielił odpowiedzi warunkowej - stwierdził, że naruszenie przepisów o zamówieniach publicznych stanowi nieprawidłowość, o ile nie można wykluczyć jego wpływu na budżet UE. Ocenę tego, czy naruszenie istotnie posiadało wpływ na szkodę w budżecie UE względnie, czy zachodziło ryzyko jej wystąpienia - Trybunał pozostawił do rozstrzygnięcia krajowemu sądowi odsyłającemu. Z perspektywy art. 267 lit. b) TFUE sposób udzielenia odpowiedzi nie powinien budzić wątpliwości.

Trybunał jednocześnie, tożsamo jak rzecznik generalna, odniósł się do kwestii wymiaru korekty finansowej dokonywanej w przypadku, w którym stwierdzone naruszenie przepisu o zamówieniach publicznych stanowiłoby nieprawidłowość. W tym zakresie Trybunał istotnie uzupełnił stanowisko rzecznik generalnej. Z opinii rzecznik generalnej wynika, że wysokość korekty finansowej można ustalić na podstawie ryczałtowego taryfikatora korekt finansowych wyłącznie wówczas, gdy w okolicznościach konkretnej sprawy nie jest możliwie ustalenie rzeczywistego wpływu stwierdzonej nieprawidłowości na budżet UE. Trybunał przy tym zastrzegł, że ryczałtowa korekta finansowa nie powinna być dokonywana wyłącznie w oparciu o przyjęty taryfikator i uwzględnione w nim ryczałtowe wskaźniki korekt. Trybunał stwierdził, że „pierwsze” (wstępne) określenie wartości korekty finansowej, może zostać dokonane za pomocą uwzględniających zasadę proporcjonalności, zryczałtowanych stawek przyjętych $\mathrm{w}$ taryfikatorze. Jednocześnie, ostateczne ustalenie korekty finansowej powinno odbywać się przy uwzględnieniu okoliczności zaszłych w sprawie, które mogą uzasadniać dokonanie korekty o wyższej lub niższej kwocie, niż to wynika $\mathrm{z}$ treści zryczałtowanego taryfikatora ${ }^{33}$.

\section{Podsumowanie}

Wyrok Trybunału w sprawie C-406/14 Wrocław - Miasto na prawach powiatu przeciwko Ministrowi Infrastruktury i Rozwoju, poprzez dostarczenie niezbędnych dyrektyw w zakresie wykładni definicji legalnej nieprawidłowości, nie tylko pozwolił na zgodne z prawem UE rozstrzygnięcie sprawy przez krajowy sąd odsyłający, ale jednocześnie w sposób trwały wpłynął na sposób wykładni pojęcia nieprawidłowości w dalszych

33 ECLI:EU:C:2016:562, pkt 51. 
sprawach rozstrzyganych przez sądy krajowe, w tym nie tylko przez sądy administracyjne ${ }^{34}$, ale również sądy powszechne ${ }^{35}$. Co kluczowe (dla ochrony uzasadnionych praw beneficjentów środków z budżetu UE) Trybunał określił kwalifikator, na podstawie którego należy rozróżnić od siebie naruszenie prawa prowadzące do ryzyka wystąpienia szkody (stanowi ono nieprawidłowość opartą na tzw. szkodzie potencjalnej) od naruszenia czysto formalnego - to drugie naruszenie nie stanowi nieprawidłowości i nie powinno prowadzić do dokonania korekty finansowej. Brak zaś określenia przedmiotowego kwalifikatora w ramach wykładni definicji legalnej nieprawidłowości prowadził w praktyce do sytuacji, w których dochodziło do stwierdzenia nieprawidłowości już w okoliczności (wyłącznie) naruszenia przepisów prawa, których ewentualny (potencjalny) wpływ na uszczerbek finansowy w budżecie UE w ogóle nie stanowił przedmiotu kontroli.

Istotne okazało się również stanowisko Trybunału w zakresie ustalania wysokości korekt finansowych. Podkreślenie zastosowania i roli zasady proporcjonalności w wymiarze korekt finansowych pozwala stwierdzić, że korektami powinna być obejmowana jedynie niezbędna kwota dofinansowania unijnego objęta nieprawidłowością, a dążenie do zastosowania proporcjonalnej korekty jest ponad określone w taryfikatorze ryczałtowe stawki korekt finansowych.

Bibliografia

Orzecznictwo

Wyrok NSA z dnia 8 stycznia 2020 r. o sygn. akt II GSK 1547/18.

Wyrok Trybunału z dnia 14 listopada 2018 r. w sprawie C-93/17 Komisja przeciwko Grecji.

Wyrok Trybunału z dnia 6 grudnia 2017 r. w sprawie C-408/16 Compania Naţională de Administrare a Infrastructurii Rutiere SA v Ministerul Fondurilor Europene - Direcţia Generală Managementul Fondurilor Externe.

Wyrok SN z dnia 8 marca 2017 r. o sygn. akt IV CSK 327/16.

Wyrok NSA z dnia 17 stycznia 2017 r. o sygn. akt II GSK 4487/16.

Wyrok NSA z dnia 13 grudnia 2016 r. o sygn. akt 1265/15.

Wyrok Trybunału z dnia 14 lipca 2016 r. w sprawie C-406/14 Wrocław - Miasto na prawach powiatu przeciwko Ministrowi Infrastruktury i Rozwoju.

Wyrok NSA z dnia 15 września 2015 r. o sygn. akt II GSK 2370/14.

Wyrok Trybunału z dnia 2 grudnia 2014 r. w sprawie C-196/13 Komisja przeciwko Włochom.

34 Zob. wyroki NSA: z dnia 17 stycznia 2017 r. o sygn. akt II GSK 4487/16; z dnia 8 stycznia 2020 r. o sygn. akt II GSK 1547/18; z dnia 13 grudnia 2016 r. o sygn. akt II GSK 1265/15.

35 Zob. wyrok SN z dnia 8 marca 2017 r. o sygn. akt IV CSK 327/16. 
Wyrok Trybunału z dnia 15 października 2014 r. w sprawie C-418/06 Królestwo Belgii przeciwko Komisji.

Wyrok NSA z dnia 20 lipca 2011 r. o sygn. akt III FSK 335/10.

Wyrok Trybunału z dnia 18 grudnia 2008 r. w sprawie C-101/07 P i C-110/07 P Coop de France betail et viande i inni przeciwko Komisji.

Wyrok Trybunału z dnia 29 października 2005 r. w sprawie C-199/03 Irlandia przeciwko Komisji.

Wyrok Trybunału z dnia 18 września 2003 r. w sprawie C-346/00 Zjednoczone Królestwo Wielkiej Brytanii i Irlandii Północnej przeciwko Komisji.

Wyrok SPI z dnia 19 czerwca 1997 r. w sprawie T-260/94 Air Inter przeciwko Komisji.

Wyrok Trybunału z dnia 8 lutego 1990 r. w sprawie C-320/88 Staatssecretaris van Financien przeciwko Shipping and Forwarding Enterprise Safe BV.

Wyrok Trybunału z dnia 17 maja 1984 r. w sprawie 15/83 Denkavit Nederland.

Wyrok Trybunału z dnia 28 marca 1979 r. w sprawie C-222/78 ICAP przeciwko Walter Beventi.

\section{Literatura}

Gruszczyński B. [w:] Dauter B., Gruszczyński B., Kabat A., Niezgódka-Medek M., Prawo o postępowaniu przed sq̨dami administracyjnymi. Komentarz, Zakamycze 2006.

Grzybowski T., Dauter B. (red.), Pytanie prejudycjalne sadu administracyjnego do Trybunału Sprawiedliwości Unii Europejskiej, SIP Lex.

Kalisz A., Reguty interpretacyjne stosowane przez ETS, „Europejski Przegląd Sądowy" 2007, nr 2.

Karwatowicz G., Odachowski J., Nieprawidłowości w zamówieniach publicznych skutkujace nałożeniem korekt finansowych, „Finanse Komunalne” 2009, nr 7-8.

Karwatowicz, G., Zawiślańska A., Korekty finansowe za naruszenie prawa zamówień publicznych w projektach unijnych, Wrocław 2013.

Łacny J., Korekty finansowe nakładane przez Komisję Europejską na państwa członkowskie za niezgodnie z prawem wydatkowanie funduszy Unii Europejskiej, Warszawa 2017.

Łacny J., Ochrona interesów finansowych Unii Europejskiej $w$ dziedzinie polityki spójności, Warszawa 2010.

Maliszewska-Nienartowicz J., Rozwój zasady proporcjonalności w europejskim prawie wspólnotowym, „Studia Europejskie” 2006.

Michalska J., Pytania prejudycjalne sądów do TS UE [w:] Zasada pierwszeństwa prawa Unii Europejskiej w praktyce działania organów władzy publicznej RP, M. Jabłoński, S. Jarosz-Żukowska (red.), Wrocław 2015.

Odachowski J., Pojęcie nieprawidłowości wykorzystania przyznanych środków w prawie UE [w:] W. Miemiec, Europejskie bezzwrotne źródła finansowania polityki regionalnej w Polsce, Wrocław 2012.

Sikora A., Praktyka Trybunału Sprawiedliwości $w$ postępowaniach na podstawie art. 267 TFUE $w$ świetle orzecznictwa i ostatniej reformy procedury, „Europejski Przegląd Sądowy" 2014, nr 11. 
Skrzydło J., Granice kompetencji Trybunału Sprawiedliwości do wydawania orzeczeń prejudycjalnych, „Europejski Przegląd Sądowy” 2017, nr 12.

Sochańska M., Stepaniuk M., Korekty finansowe w procesie udzielania zamówień publicznych. Kontrola postępowań współfinansowanych ze środków unijnych, Warszawa 2019.

Taborowski M., Polskie sądy zobowiązane do zwrócenia się z pytaniem prejudycjalnym do ETS w świetle wyroku Lyckeskog, „Europejski Przegląd Sądowy” 2008, nr 8.

Wróbel A., Pytania prawne sq̨dów państw członkowskich do Trybunału Sprawiedliwości Unii Europejskiej [w:] Stosowanie prawa Unii Europejskiej przez sądy, A. Wróbel (red.),Warszawa 2010.

Inne

Opinia rzecznik generalnej E. Sharpston przedstawiona w dniu 17 listopada $2015 \mathrm{r}$. w sprawie C-406/14 Wrocław - Miasto na prawach powiatu przeciwko Ministrowi Infrastruktury i Rozwoju.

Opinia rzecznika generalnego N. Jääskinena przedstawiona w dniu 30 kwietnia 2014 r. w sprawie C-417/12 P Dania przeciwko Komisji.

Zalecenia TSUE dla sądów krajowych dotyczących składania wniosków o wydanie orzeczenia w trybie prejudycjalnym (2018/C 257/01).

Wykładnia definicji legalnej nieprawidłowości w świetle wyroku Trybunału Sprawiedliwości Unii Europejskiej w sprawie C-406/14 pytanie prejudycjalne WSA w Warszawie

Streszczenie

Sąd krajowy (WSA w Warszawie) posiadał wątpliwość w zakresie wykładni pojęcia nieprawidłowości zdefiniowanego w art. 2 pkt 7 rozporządzenia 1083/2006. Powyższa wątpliwość stała się przyczyną wystąpienia do Trybunału z pytaniem prejudycjalnym. Trybunał w wydanym wyroku określił przesłankę, na podstawie której należy odróżnić naruszenie powodujące ryzyko wystąpienia szkody w budżecie UE od naruszenia formalnego, które nie posiada jakiegokolwiek negatywnego wpływu na budżet UE. Dodatkowo Trybunał odniósł się do kwestii ustalenia wartości korekty finansowej, mimo iż sąd zadający pytanie prejudycjalne nie posiadał wątpliwości w tym zakresie. Trybunał podkreślił, iż korekta finansowa w każdym przypadku powinna być proporcjonalna. W sytuacjach, gdy wartość korekty finansowej ustalana jest na podstawie ryczałtowego taryfikatora, należy zweryfikować, czy taka korekta będzie proporcjonalna oraz, czy występują w sprawie okoliczności pozwalające na obniżenie lub podwyższenie korekty w stosunku do przyjętego ryczałtowego wskaźnika.

Słowa kluczowe: fundusze UE, nieprawidłowości w projektach UE, zwrot dofinansowania UE, korekty finansowe, orzeczenie prejudycjalne 


\section{Interpretation of the Definition of Legal Irregularity in the Judgment of the Court in Case C-406/14 - a Preliminary Question from the WSA in Warsaw}

\section{Abstract}

The domestic court (WSA in Warsaw) had doubts as to the interpretation of the notion of irregularities defined in Art. 2 point 7 of Regulation 1083/2006. The above doubt became the reason for referring a question to the Court for a preliminary ruling. In its judgment, the Court defined the condition on the basis of which it is necessary to distinguish a breach causing a risk of harm to the EU budget from a formal breach which does not have any negative impact on the EU budget. In addition, the Tribunal referred to the issue of determining the value of the financial correction - even though the court making the request for a preliminary ruling had no doubts in this respect. The Court underlined that the financial correction in each case should be proportionate. In situations where the value of a financial correction is determined on the basis of a flat-rate tariff, it should be verified whether such a correction will be proportional and whether there are circumstances allowing for a reduction or increase of the correction in relation to the adopted flat-rate ratio.

Keywords: EU funds, irregularities in EU projects, reimbursement of the EU grant, financial correction, preliminary ruling 